\title{
Knowledge Sharing and its relation to Organizational Citizenship Behaviors as Perceived by Staff Nurses
}

\author{
Ayaa Ismail Ibrahim ${ }^{1}$, Fawzia Farouk Kamel ${ }^{2}$ and Shimaa Mohamed Ibrahim ${ }^{3}$ \\ (1) Nursing Specialist, Technical Institute of Nursing/Benha University, Egypt, (2) Assistant \\ professor of Nursing Administration, Faculty of Nursing/ Benha University, Egypt and (3) Lecturer \\ of Nursing Administration, Faculty of Nursing/Benha University, Egypt
}

\begin{abstract}
Background: Building a knowledge sharing culture is necessary for staff nurses to enhance their organizational citizenship behaviors. Aim of study: Was to assess knowledge sharing and its relation to organizational citizenship behaviors as perceived by staff nurses. Research design: A descriptive correlational design was used. Setting: The study was conducted at all critical care units in Benha University Hospital. Subject: A convenience sample consisted of (200) staff nurses who are responsible for providing direct nursing care activities to patients in the above-mentioned study setting and have at least three years of job experience. Tools of data collection: Two tools were used for data collection; first tool: knowledge sharing questionnaire, and the second tool: organizational citizenship behaviors questionnaire. Results: $89.5 \%$ of staff nurses had a high perception level of knowledge sharing and $87.0 \%$ had high level of organizational citizenship behaviors. Conclusion: There was a highly statistically significant correlation between knowledge sharing and organizational citizenship behaviors. Recommendations: Enhance staff nurses' awareness of knowledge sharing and organizational citizenship behaviors by conducting educational programs, workshops, and conferences to improve outcomes related to patients and the organization.
\end{abstract}

Key words:Knowledge sharing, Organizational Citizenship Behaviors, Staff nurses.

\section{Introduction}

Knowledge is crucial to any organization, for improving decision-making, increasing productivity and creating a sustainable competitive advantage, numerous organizations are continually searching for solutions to effectively acquire, store, share and apply knowledge within the internal and external environments .Knowledge sharing is the essential component of knowledge management (Karamat et al., 2019; Bagais et al., 2020).

Healthcare providers are considered knowledge workers to the extent that providing the health care requires constant updating of knowledge and skills to serve the needs of the patients. So, knowledge sharing

practices among healthcare practitioners have significant implications for the quality and efficiency of healthcare services and represent a critical factor for the organization's success (Maheshwar et al., 2020; Christofi et al., 2021).

Knowledge sharing is interpersonal communication that involves communicating and receiving knowledge from others. Also, knowledge sharing merges into social interaction, by which staff nurses exchange knowledge through communication channels such as conversations, meetings, workshops, thus knowledge sharing requires staff nurses to participate in the process actively and 
cooperate with each other closely (Curado and Vieira, 2019; Fahmi et al., 2020)

Knowledge sharing is the process of interchanging tacit and explicit knowledge to jointly create new knowledge among staff nurses. Tacit knowledge sharing is defined as sharing and exchanging staff nurse's personal experiences, expertise and skills. Meanwhile while, explicit knowledge sharing is the process of sharing codified knowledge and formal information within an organization such as documents and reports, procedures and policies or handbooks (Lee et al., 2016; Novitasari et al., 2021).

Knowledge sharing is importance at the individual and organizational levels. The importance of individual knowledge sharing is in helping individuals to perform their functions more effectively, helping them to stay in their jobs, promoting career advancement and personal development, and a sense of satisfaction for staff nurses. The organizational importance of knowledge sharing reflected in increased efficiency improvement, reduced training costs and reduced risk of uncertainty (Al-Saffara and Obeidat, 2020).

Knowledge sharing also, act as a basis for empowering staff nurses to show voluntary behaviors and go beyond the formal obligation in favor of the organization, organizational citizenship behaviors include those voluntary behaviors. Knowledge sharing will allow staff nurses to understand the duties and responsibilities, organization and the top management's judgments and behaviors resulting in staff nurses engage more in organizational citizenship behaviors (Akturan and Cekmecelioglu, 2016).

Organizational citizenship behaviors are discretionary, beyond role behaviors that are not explicitly recognized by the formal reward system but are considered important in promoting effectiveness, enhance job satisfaction, job retention and the feeling of responsibility among staff nurses resulting in decrease need for supervision that allow managers to focus on important job function and encourage staff nurses to get involved in giving constructive suggestions (Hossain, 2020; Yaakobi and Weisberg, 2020; Meniado, 2021).

Organizational citizenship behaviors have five dimensions, altruism (voluntarily helping other), courtesy (being polite and considerate of others), civic virtue (representing well and supporting the organization), conscientiousness (planning ahead to avoid colleagues and oneself feeling overwhelmed with work) and sportsmanship (not complaining about work). Altruism and courtesy are considered organizational citizenship behaviors directed toward other, while civic virtue, conscientiousness and sportsmanship are directed toward the organization (Rosle et al., 2021).

Knowledge sharing and

Organizational citizenship behaviors are closely related because both behaviors are taken into account as a discretionary behavior and both have a positive relationship with organizational performance, the emotional bonding with the organization and a greater sense of cooperation through knowledge sharing can become an important driver of organizational citizenship behaviors (Jalili and Salemipour 2019; Ficapal, Enache and Torrent, 2020).

\section{Significance of the study:}

Health care field is a knowledge rich community which deals with patients' lives and wellness thus knowledge sharing among nurses is a must. Knowledge sharing has an important role to facilitate growth of knowledge to increase its value. However, it is difficult to impose knowledge sharing because knowledge is created and stored with organizational members who may be less 
willing to share their knowledge (Zakaria, 2019).

Organizational citizenship behaviors protect organizations from destructive and undesired behaviors and increase the leaning to cooperate and share information among nurses, and develop sense of responsibility among them (Hossain, 2020). Staff nurses who practice Organizational citizenship behaviors are willing to cooperate and increase their engagement beyond the set duties and rewards provided by the organization with the intention of achieving more significant goals (Habeeb, 2019). So that this study was concerned with assessing knowledge sharing and its relation to organizational citizenship behaviors as perceived by staff nurses at Benha University Hospital.

\section{Aim of the study}

The study aimed to assess knowledge sharing and its relation to organizational citizenship behaviors as perceived by staff nurses.

\section{Research questions:}

- What is the knowledge sharing level among staff nurses?

- What is the organizational citizenship behaviors level among staff nurses?

- What is the relation between knowledge sharing and organizational citizenship behaviors among staff nurses?

\section{Subjects and Method}

\section{Research design:}

Descriptive correlational research design was used to carry out this study.

\section{Setting:}

The current study was conducted in all critical care units at Benha University Hospital, Qalyubia governorate; Emergency intensive care unit, Coronary care unit, General ICU, Dialysis care unit, Chest ICU, Chest and cardiac ICU, Dialysis care pediatric unit, Pediatric ICU, Incubator units, Intermediate ICU, Hepatic ICU and Psychiatric ICU

\section{Subject:}

The subjects of the study consisted of convenience staff nurses (200) staff nurses who are responsible for providing direct nursing care activities to patient working in the above mentioned study setting and having at least three years of job experience and accept to participate in study.

\section{Tools of data collection:}

Data of present study was collected by using two tools namely:

\section{First tool: knowledge sharing questionnaire:}

It was developed by researcher after reviewing the related literature (Wang, 2010; Mallasi and Ainin, 2015; Obrenovic et al., 2020) to assess knowledge sharing levels among staff nurses; it consisted of two parts:

Part (1): Personal data department, age, gender, marital status, level of education, years of job experience, training courses about knowledge sharing and knowledge sharing methods used by staff nurses).

Part (2): Knowledge sharing questionnaire: It consisted of 26 items divided under two main dimensions; Individual knowledge sharing (21) items and organizational knowledge sharing (5) items. The individual knowledge sharing dimension divided into five sub dimensions as following; knowledge sharing behavior (4) items, enjoyment in helping other (3) items, selfefficacy (4) items, reputation (4) items, knowledge sharing about best practice (3) items and knowledge sharing about personal mistakes(3) items. 


\section{Scoring system:}

Responses of staff nurses were measured on a three point Likert scale as follow; agree (3) point, neutral (2) point, disagree (1) point. The scores for each area of the items were summed up and the total divided by the number of the items, giving a mean score for the part. These scores were converted into a percent score. Range of scores for nurses toward knowledge sharing were (54-78), cut point was done at $60 \%=47$ point score; high knowledge sharing level equal or more than $75 \% \quad(\geq 59)$ point, moderate knowledge sharing level from 60 to less than $75 \%$ (=47$<59$ ) point, low knowledge sharing level less than $60 \%(<47)$ point.

\section{Second tool: organizational citizenship questionnaire:}

It was developed by researcher after reviewing the related literature (Organ, Podsakoff and Mackenzie 2015; Abd-El halim, 2018; Kim et al., 2020) to assess Organizational citizenship behaviors level among staff nurses. It consisted of (38) items divided into five dimensions; conscientiousness (9) items, civic virtue (9) items, altruism (6) items, Sportsmanship (8) items and courtesy (6) items.

\section{Scoring system:}

Responses of staff nurses were scored based on a three point Likert scale as follow; always (3) point, sometimes (2) point, never (1) point. The scores for each area of the items were summed up and the total divided by the number of the items, giving a mean score for the part. These scores were converted into a percent score. Range of scores for nurses toward organizational citizenship behaviors were (79-109), cut point was done at $60 \%=69$ point score; High level of organizational citizenship behaviors $\geq 75 \%$ ( $\geq 86$ ) point, moderate level of organizational citizenship behaviors level from 60 to $<75 \%$ (69- <86) point and low level of organizational citizenship behaviors $<60 \%$ (<69) point.

\section{Ethical considerations}

Before conducting the study, the respondent rights were protected by ensuring voluntary participation, so the informed consent was obtained from each participant after explaining the aim of the study, its potential benefits and methods for filling data collection tools. The respondent rights to withdraw from the study at any time were assured. Confidentiality of data obtained was protected by allocation code number to the questionnaire sheets. Subjects were informed that the content of the tools used for the study purpose only.

\section{Validity of tools}

The tools were tested for face and content validity by panel of experts consisted of five experts in the related field to check the relevancy and accuracy of the tools of data collection; (1) professor of nursing administration from Tanta University, (1) assistant Professor of Nursing Administration from Menofia University, (1) assistant Professors of Nursing Administration from Cairo University and (2) assistant Professors of Nursing Administration from Benha University. According to experts' opinions, modification was done based on their comments such as modify some phrases and add some phrases to give right meaning for phrase which didn't understood clearly and adding or deleting some items.

\section{Reliability of tool}

The reliability was done by Cronbach's Alpha coefficient test to determine the effect to which the tool was related to each other. The test of reliability knowledge sharing questionnaire was (0.832), the test of reliability for Organizational citizenship behaviors questionnaire was (0.811). 


\section{Pilot Study}

A pilot study was conducted on $10 \%$ of the Pilot study was conducted at November 2019 to assess tool clarity and applicability. The study was tested on $10 \%$ of total subjects (20 staff nurses) from Benha University Hospital. It had served in estimating the time needed for filling the questionnaire. As a result of pilot study, no modification was done and items were understandable, so staff nurses were included in the main subject and the time needed to fill the sheet was about (10-15) minutes.

\section{Field work}

The actual data collection took about three months from beginning of December 2020 to end of February 2021. At first, the researcher met the director of the study setting to explain the aim of the study, obtain official permission for data collection. Then the researcher met staff nurses during available work time while don't interfere with their duties and explained the aim and nature of the study and the method of filling questionnaire, the knowledge sharing questionnaire and organizational citizenship questionnaire were distributed and filled by the staff nurses during morning shift from 11.00 a.m-1.00 p.m. The researcher collected data 3 days per week. The number of collected questionnaire from staff nurses per day ranged from 5 to 7 sheets. The time needed by staff nurses to fill each tool was ranged between (10-15) minutes. The presence of researcher all times to clarify each ambiguity and answered any questions, then the tool was collected and checked for completeness to ensure absence of any missed data.

\section{Statistical analysis}

After completion of data collection, the data was organized, analyzed and tabulated .data entry and statistical analysis was done using Statistical Package for Social
Sciences (SPSS ver. 25.0). Descriptive statistics were applied (e.g., mean, standard deviation, frequency and percentages). In addition, correlation coefficient (r) test was used to estimate the closeness association between variables. A highly significant level value was considered when $\mathrm{p}$-value $<0.001$, while $\mathrm{p}$-value $>0.05$ indicates non- significant results.

\section{Results:}

Table (1): Shows that, more than two thirds $(71 \%)$ of the staff nurses were aged less than 30 years old with $\mathrm{X}^{-} \pm \mathrm{SD}(28.87 \pm 6.99)$. Regarding to their gender more than three quarters $(82.5 \%)$ of them was female. According to their marital status more than half $(57.5 \%)$ of staff nurses were single. In relation to their level of education about two thirds $(67 \%)$ of them had technical nursing institute, the majority (87\%) of them were less than 10 years of experience with $\mathrm{X}^{-} \pm \mathrm{SD}$ $(8.83 \pm 7.58)$, regarding training courses about knowledge sharing more than half $(58 \%)$ of them hadn't attended training courses about knowledge sharing.

Figure (1): Clearly that, the majority $(89.5 \%)$ of staff nurses had high perception levels regarding knowledge sharing while, the lowest percentage $(10.0 \%)$ of them had moderate perception levels of knowledge sharing.

Table (2): Demonstrates that, the total score of knowledge sharing among staff nurses was $(67.97 \pm 4.42)$, Also the highest mean score $(13.26 \pm 1.78)$ of staff nurses' knowledge sharing was related to organizational knowledge sharing, followed by individual knowledge sharing (13.26 \pm 1.78).

Table (3): Shows that, the highest mean score $(8.59 \pm 0.72)$ was related to enjoy 


\section{$\underline{\text { Ayaa Ismail Ibrahim, Fawzia Farouk Kamel and Shimaa Mohamed Ibrahim }}$}

in helping other followed by reputation (11.17 \pm 1.21$)$ followed by knowledge sharing about personal mistakes $(7.83 \pm 1.01)$, followed by knowledge sharing behavior $(10.12 \pm 1.61)$ and the lowest mean score $(7.32 \pm 0.98)$ was related to knowledge sharing about best practice.

Figure (2): Clarifies that, the majority $(87.0 \%)$ of the staff nurses had high Organizational citizenship behaviors levels while; the lowest percentage $(12.0 \%)$ of them had moderate Organizational citizenship behaviors levels.
Table (4): Displays that, the highest mean score $(16.61 \pm 1.78)$ was related to altruism followed by courtesy (16.12 \pm 2.63$)$, followed by conscientiousness (22.30 \pm 1.78$)$, followed by sportsmanship (18.84 \pm 3.02$)$ while, the lowest mean score $(20.57 \pm 2.82)$ was related to virtue dimension.

Table (5): Presents that, there was highly statistically significant positive correlation between total knowledge sharing and total organizational citizenship behaviors.

Table (1): Percentage distribution of the staff nurses according to their personal characteristics $(n=200)$

\begin{tabular}{|c|c|c|}
\hline Personal characteristics & Frequency & $\%$ \\
\hline \multicolumn{3}{|l|}{ Age(years) } \\
\hline $20<30$ & 142 & 71.0 \\
\hline $30<40$ & 50 & 25.0 \\
\hline$\geq 40$ & 8 & 4.0 \\
\hline $\mathrm{X}^{-} \pm \mathrm{SD}$ & \multicolumn{2}{|l|}{$28.87 \pm 6.99$} \\
\hline \multicolumn{3}{|l|}{ Sex } \\
\hline Male & 35 & 17.5 \\
\hline Female & 165 & 82.5 \\
\hline \multicolumn{3}{|l|}{ Marital status } \\
\hline Unmarried & 115 & 57.5 \\
\hline Married & 85 & 42.5 \\
\hline \multicolumn{3}{|l|}{ Level of education } \\
\hline Diploma in nursing & 38 & 19.0 \\
\hline Technical nursing institute & 134 & 67.0 \\
\hline Bachelor of nursing & 28 & 14.0 \\
\hline \multicolumn{3}{|l|}{ Years of experience } \\
\hline$<10$ & 174 & 87.0 \\
\hline $10<20$ & 20 & 10.0 \\
\hline$\geq 20$ & 6 & 3.0 \\
\hline $\mathrm{X}^{-} \pm \mathrm{SD}$ & \multicolumn{2}{|c|}{$8.83 \pm 7.58$} \\
\hline \multicolumn{3}{|c|}{ Training courses about knowledge sharing } \\
\hline Yes & 84 & 42.0 \\
\hline No & 116 & 58.0 \\
\hline
\end{tabular}


Knowledge Sharing and its relation to Organizational Citizenship Behaviors as Perceived by Staff Nurses

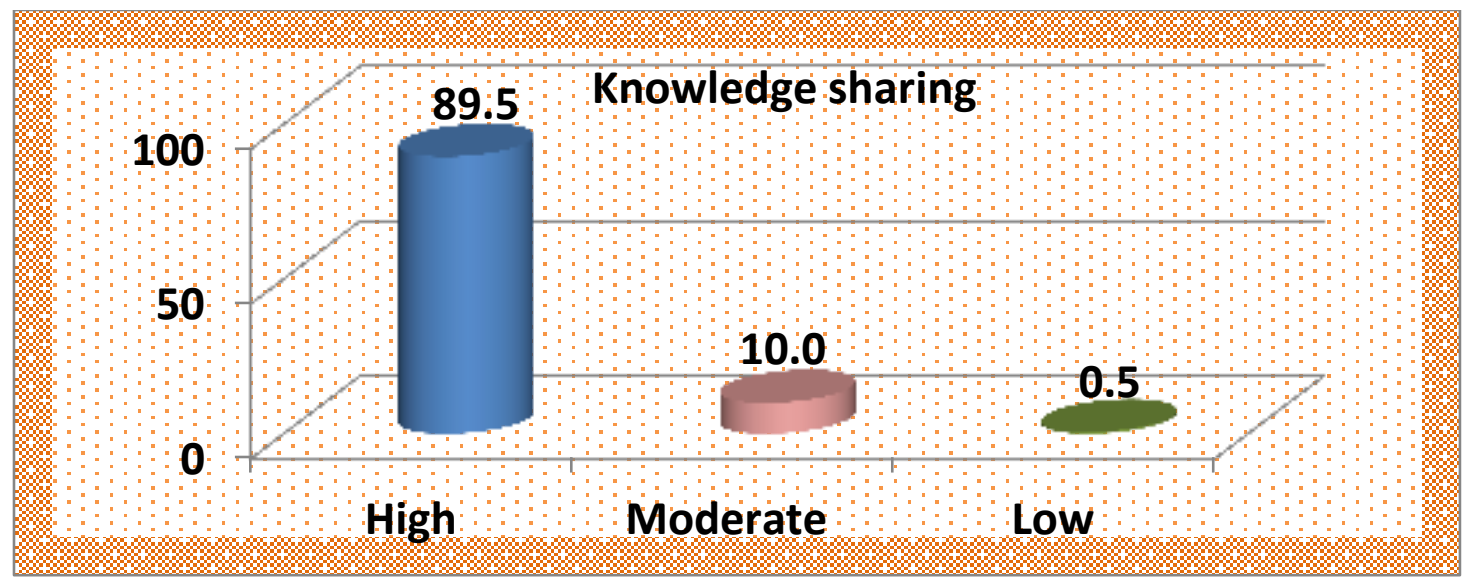

Figure (1): Staff nurses' knowledge sharing levels as perceived by staff nurses

Table (2): Ranking and mean scores and standard deviation of knowledge sharing dimensions as perceived by staff nurses

\begin{tabular}{|c|c|c|c|c|c|c|}
\hline \multicolumn{2}{|c|}{ knowledge sharing } & \multirow{2}{*}{$\begin{array}{l}\text { Maximum } \\
\text { score }\end{array}$} & \multirow{2}{*}{$\begin{array}{l}\text { Range } \\
44-62\end{array}$} & \multirow{2}{*}{$\begin{array}{l}\mathrm{X}^{-} \pm \mathrm{SD} \\
54.71 \pm 3.65\end{array}$} & \multirow{2}{*}{$\begin{array}{l}\text { Mean } \\
\% \\
86.8 \\
\end{array}$} & \multirow{2}{*}{$\begin{array}{l}\text { Rank } \\
2\end{array}$} \\
\hline$\overline{I I}$ & $\begin{array}{ll}\text { Individual knowledge } \\
\text { sharing }\end{array}$ & & & & & \\
\hline$\overline{\mathrm{II}}$ & $\begin{array}{l}\text { Organizational } \\
\text { knowledge sharing }\end{array}$ & 15 & $5-15$ & $13.26 \pm 1.78$ & 88.4 & 1 \\
\hline \multicolumn{2}{|c|}{ Total scale } & 78 & $54-78$ & $67.94 \pm 4.42$ & & \\
\hline
\end{tabular}

Table (3): Ranking and mean scores and standard deviation of individual knowledge sharing dimension as perceived by staff nurses

\begin{tabular}{|c|c|c|c|c|c|}
\hline $\begin{array}{l}\text { Individual knowledge } \\
\text { sharing }\end{array}$ & \begin{tabular}{|l|} 
Maximum \\
score
\end{tabular} & Range & $\mathrm{X}^{-} \pm \mathrm{SD}$ & Mean \% & Rank \\
\hline Knowledge sharing behavior & 12 & $7-12$ & $10.12 \pm 1.61$ & 84.3 & 4 \\
\hline Enjoyment in helping other & 9 & $5-9$ & $8.59 \pm 0.72$ & 95.4 & 1 \\
\hline Self-efficacy & 12 & $6-12$ & $9.81 \pm 1.44$ & 81.7 & $\overline{5}$ \\
\hline Reputation & 12 & $8-12$ & $11.17 \pm 1.21$ & 93.1 & 2 \\
\hline $\begin{array}{l}\text { Knowledge sharing } \text { about } \\
\text { best practice }\end{array}$ & 9 & $5-9$ & $7.32 \pm 0.98$ & 81.3 & 6 \\
\hline $\begin{array}{l}\text { Knowledge sharing about } \\
\text { personal mistakes }\end{array}$ & 9 & $5-9$ & $7.83 \pm 1.01$ & 87.0 & 3 \\
\hline
\end{tabular}




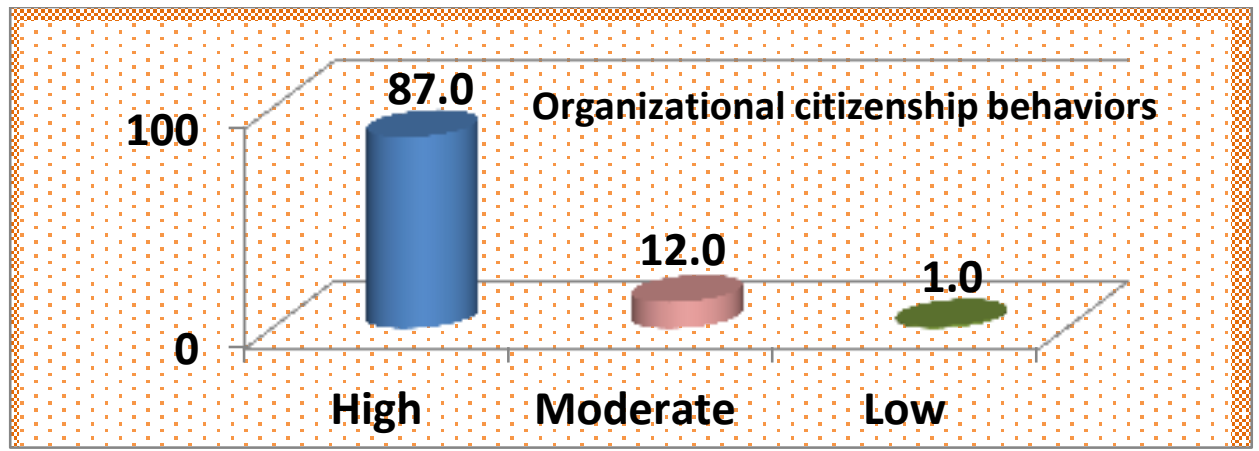

Figure (2): Organizational citizenship behaviors levels as reported by staff nurses.

Table (4): Ranking and mean scores and standard deviation of organizational citizenship behaviors as reported by staff nurses

\begin{tabular}{|l|l||l||l|l||l||}
\hline $\begin{array}{l}\text { Organizational } \\
\text { citizenship } \\
\text { behaviors }\end{array}$ & Score & Range & $X^{-} \pm$SD & $\begin{array}{l}\text { Mean } \\
\%\end{array}$ & Rank \\
\hline Conscientiousness & 27 & $15-25$ & $22.30 \pm 1.78$ & 82.6 & 3 \\
\hline Civic virtue & 27 & $15-27$ & $20.57 \pm 2.82$ & 76.2 & 5 \\
\hline Altruism & 18 & $12-18$ & $16.61 \pm 1.78$ & 92.3 & 1 \\
\hline Sportsmanship & 24 & $10-24$ & $18.84 \pm 3.02$ & 78.5 & 4 \\
\hline Courtesy & 18 & $6-18$ & $16.12 \pm 2.63$ & 89.6 & 2 \\
\hline Total scale & 114 & $79-109$ & $\mathbf{9 4 . 4 6} \pm \mathbf{7 . 1 9}$ & & \\
\hline
\end{tabular}

Table (5): Correlation between knowledge sharing and organizational citizenship behaviors

\begin{tabular}{|c|c|c|}
\hline & \multicolumn{2}{|c|}{$\begin{array}{r}\text { Total organizational citizenship } \\
\text { behaviors }\end{array}$} \\
\hline & $\mathbf{r}$ & $P$ value \\
\hline Total knowledge sharing & 0.529 & $0.000 * *$ \\
\hline
\end{tabular}

**A highly statistical significant difference $(\mathrm{P} \leq \mathbf{0 . 0 0 1})$. 


\section{Discussion}

In relation to total knowledge sharing level among staff nurses, the result of the present study revealed that, the majority of staff nurses had high perception level regarding knowledge sharing while, the lowest percentage of them had moderate perception levels. From the investigator point of view the head nurses support and motivate the staff nurses to share knowledge. Also, staff nurses share knowledge with their colleagues as they develop relationships with them and anticipate receiving knowledge in the future.

The present study result was consistent with Elsaid et al., (2020), study about "Relationship between Organizational Commitment and Knowledge Sharing among Staff Nurse" they discovered that the majority of staff nurses had high level of total knowledge sharing.

On the contrary the present study result was disagreed with Al-Dalaien et al., (2020) study about " Investigate the extrinsic and intrinsic motivational factors of knowledge transfer in the hospitals" they showed that staff nurses' perception level regarding knowledge sharing was moderate.

Concerning, ranking and mean scores and standard deviation of knowledge sharing dimensions as perceived by staff nurses, the findings of the present study demonstrated that the highest mean score of staff nurses' knowledge sharing was related to organizational knowledge sharing followed by individual knowledge sharing. From the investigator point of view the staff nurses work as a cooperative team. A team culture that is cooperative in nature can stimulate social exchange; it creates a high level of trust that is required for knowledge sharing.
The same finding reported by Zakaria, (2019) study about "Relationship between Organizational Commitment and Knowledge Sharing among Staff Nurses" who founded that majority of staff nurses had high level of both knowledge sharing dimension.

On the other side, the present study result unsupported by Demsash et al., (2021) who revealed that more than two thirds of healthcare providers didn't have opportunity, supportive leadership and resource allocation for knowledge sharing practice.

Concerning, ranking and mean scores and standard deviation of individual knowledge sharing, the findings of the present study indicated that, the highest mean score was related to enjoyment in helping other, followed by reputation, followed by knowledge sharing about personal mistakes, followed by knowledge sharing behavior and the lowest mean score was related to knowledge sharing about best practice dimension. From the investigator point of view the staff nurses are motivated to share knowledge with others because they consider helping others and sharing knowledge is important to improve quality of care.

The finding of the present study was consistent with Obrenovic et al, (2020) study about " The Enjoyment of Knowledge Sharing: Impact of Altruism on Tacit Knowledge-Sharing Behavior" they indicated that, individuals experiencing enjoyment in helping others are more willing to share knowledge. On the contrary, the present study result was inconsistent with Almasry, (2019) who found that, the highest mean score of knowledge sharing dimension was related to reputation among staff nurses. 
In the relation to total Organizational citizenship behaviors level among staff nurses, the result of the present study clarified that the majority of the staff nurses had high level regarding organizational citizenship behaviors and the lowest percentage of them had moderate level regarding organizational citizenship behaviors. From the investigator point of view when the knowledge sharing becomes common in an organization, the organizational citizenship behaviors can be expected to increase. As knowledge sharing allows staff nurses to show voluntary behaviors.

The present study result agreed with Fiaz et al., (2018) and Mustafa et al., (2021) who revealed that, the citizenship behavior level was high. The present study results unsupported by Abo Amer, (2020) and Jafari et al., (2020) they found that, the mean score of the organizational citizenship behaviors was moderate.

Concerning, ranking and mean scores and standard deviation of organizational citizenship behaviors dimensions among staff nurses, the findings of the present study displayed that, the highest mean score was related to altruism followed by courtesy, followed by conscientiousness, followed by sportsmanship and the lowest mean score was related to civic virtue dimension. From the investigator's point of view the staff nurses prefer to cooperate with their colleagues to carry out the tasks but in other times, the workload is increased, so nurses keep away from meetings and making suggestions and avoid volunteering in problem solving.

Additionally, the present study finding was in the same line with El-Nahas, (2020) study about "Organizational citizenship behavior and quality of work life among nurses " in Egypt who revealed that, the nurses obtained the highest score for the altruism dimension.

On the contrary, the present study result disagreed with Safan et al., (2018) study about "The Relationship between Organizational Citizenship Behavior and Organizational Climate among Nursing Staff" in Egypt, they showed that, mean score of sportsmanship obtained the highest mean score of all dimensions of Organizational citizenship behaviors, and the lowest mean score was obtained to conscientiousness.

In the findings of the present study, it was showed that there was a highly statistical significance positive correlation between knowledge sharing and organizational citizenship behaviors. This means that, staff nurses with higher level of knowledge sharing engaged more in organizational citizenship behaviors. From researcher point of view, the knowledge sharing is a considerably important element in terms of ensuring cooperation among staff nurses, developing awareness for taking responsibility and enhancing the commitment toward the values of the organization which could motivate and encourage them to extensively exhibit voluntary helping behaviors.

The present study result was in agreement with Helexandra, (2020) study about "The Influence of Knowledge Sharing, Servant Leadership, Organizational Culture on Organizational Citizenship Behavior on Human Resources" in Indonesia, who revealed that there was a positive and significant influence of knowledge sharing on Organizational citizenship behaviors. The present study finding was inconsistent with, Dehghani et al., (2015) who found in their study on Kharazmi University employees in Iran that, there is no relation between 
knowledge sharing with courtesy and sportsmanship.

\section{Conclusion}

The majority of staff nurses had high perception levels regarding knowledge sharing and the highest mean score was related to organizational knowledge sharing followed by individual knowledge sharing. Also, the majority of staff nurses had high levels regarding Organizational citizenship behaviors and the highest mean score was related to altruism, followed by courtesy, followed by conscientiousness followed by sportsmanship while, the lowest mean score was related to civic virtue. Finally, there was a highly statistical significance correlation between knowledge sharing and organizational citizenship behaviors.

\section{Recommendations}

-Pay attention to the staff nurses' needs, interests, motivation, and appreciation of their effort in knowledge sharing.

-Establish a supportive work environment, which in turn, will motivate staff nurses to engage in organizational citizenship behaviors.

-Encourage open communication among staff nurses through conferences meetings to share best practices.

-Enhance staff nurses' awareness about knowledge sharing and organizational citizenship behaviors by conducting educational programs, workshops and conferences to improve outcomes related to patient and the organization.

-Develop a reward system to enhance knowledge sharing and OCBs.

\section{References}

Abd-Elhalim, E. (2018). Relationship between Staff Nurses' Job Autonomy and Organizational Citizenship at Benha
University Hospital, Unpublished master thesis, Benha University,60-61.

Abo Amer, E. (2020). Relation between Nurses' Perception of ethical work climate and Organizational Citizenship Behavior. Published master thesis, Helwan University, 55-57.

Akturan, A. and Cekmecelioglu, H. (2016). The effects of knowledge sharing and organizational citizenship behaviors on creative behaviors in educational institutions. Procedia-Social and Behavioral Sciences, 235(6): 342-350.

Al-Dalaien, A., Drus, S., Kasim, H. and AlOqaily, A. (2020). Investigate the extrinsic and intrinsic motivational factors of knowledge transfer in the hospitals. Journal of Computer Science, 16(1): 92-104.

Almasry, A. (2019). Relationship between Nurses-Physicians Collaboration and Knowledge Sharing Behavior. Unpublished master thesis, Alexandria University, 54-55.

Al-Saffara, N. and Obeidat, A. (2020). The effect of total quality management practices on employee performance: The moderating role of knowledge sharing. Management Science Letters, 10(2).1077-90.

Bagais, O. Aljaaidi, K. and Al-moataz, E. (2020). Knowledge Sharing among Accounting Students: An Exploratory Study. The Journal of Asian Finance, Economics and Business, 7(11): 557-561.

Christofi, Battisti and Graziano (2021). Intellectual capital, knowledge sharing and equity crowd funding. Journal of Intellectual Capital, 22(1): 95-121.

Curado, C. and Vieira, S. (2019). Trust, knowledge sharing and organizational commitment in SMEs, Personnel Review Journal, 48(6):1449-1468.

Dehghani, M., Hayat, A., Kojuri, J. and Esmi, K. (2015). Role of organizational citizenship behavior in promoting knowledge 
sharing. Journal of Health Management and Informatics, 2(4): 126-131.

Demsash, A., Chakilu, B. and Mazengia, A. (2021). Knowledge Sharing Practice and Its Associated Factors Among Healthcare Providers at University of Gondar Comprehensive Specialized Hospital, North West Ethiopian: Cross-sectional Study. Research square Journal, 4(1):1-19.

El-Nahas, (2020). Organizational citizenship behavior and quality of work life among nurses in Port Said Hospitals, published master thesis, El-Mansoura University: 89-90. Elsaid, E., Fakhry, S. and Abd Rabou, H. (2020). Relationship between Organizational Commitment and Knowledge Sharing among Staff Nurses. Egyptian Journal of Health Care, 11(1): 306-317.

Fahmi, K., Kurniawan, T., Cahyono, Y., Sena, A., Suhadarliyah, P., Sugianto, A., Amelia, D., Musnaini, S., Hasbullah, H., Jihadi, M., Wijoyo, H. and Purwanto, A. (2020). Did Servant, Digital and Green Leadership Influence Market Performance? Evidence from Indonesian Pharmaceutical Industry. Systematic Reviews in Pharmacy, 11 (9): 642-653.

Fiaz, M., Amir A., Su, Q. and Nader, A. (2018). How to save the saviors?: Relationship between organizational justice and citizenship behavior. The Journal of Developing Areas, 52(1): 45-58.

Ficapal, P., Enache, M. and Torrent, J. (2020). Linking Perceived Organizational Support, Affective Commitment and Knowledge Sharing with Prosocial Organizational Behavior of Altruism and Civic Virtue. Sustainability, 12(24): 1-20.

Habeeb, S. (2019). A proposed instrument for assessing organizational citizenship behavior in BFSI companies in India, Cogent Business and Management Journal, 6(1): 1-20.

Helexandra, L., (2020). The Influence of Knowledge Sharing, Servant Leadership,
Organizational Culture on Organizational Citizenship Behavior on Human Resources. Published Ph.D thesis, Faculty of Economics, University of Jakarta: 157-158. Retrieved from http://repository.unj.ac.id/13128/ Accessed at June1, 2020.

Hossain, M. (2020). Organizational Citizenship Behavior and Organizational Commitment among Clinical Nurses in Bangladesh. Open Journal of Nursing, 10(7): 693-704.

Jafari, M., Ghasemyani, S., Sadeghifar, J., Shams, L. and Naderimanesh, K. (2020). Relationship between Organizational Citizenship Behavior and Social Capital: Survey from Hospital Setting. Hospital topics Journal, 98(3): 81-88.

Jalili, Y. and Salemipour, F. (2019). Group organizational citizenship behavior and knowledge sharing. VINE Journal of Information and Knowledge Management Systems, 50 (1): 117-135.

Kim, H., Chen, Y. and Kong, H. (2020). Abusive Supervision and Organizational Citizenship Behavior: The Mediating Role of Networking Behavior. Sustainability, 12(1): 1-18.

Karamat, J., Shurong, T., Ahmad, N., Afridi, S., Khan, S. and Mahmood, K. (2019). Promoting healthcare sustainability in developing countries: analysis of knowledge management drivers in public and private hospitals of Pakistan, International Journal of Environmental Research and Public Health, 16(3):1-24.

Lee, J., Shiue, Y. and Chen, C. (2016). Examining the impacts of organizational culture and top management support of knowledge sharing on the success of software process improvement. Computers in Human Behavior, 54(2): 462-474.

Maheshwar, B., Sarrion, M., Motiani, M., Sullivan, S. and Chandwani, R., (2020). Exploration of factors affecting the use of 
Web 2.0 for knowledge sharing among healthcare professionals: an Indian perspective. Journal of Knowledge Management, 25(3):1367-3270.

Mallasi, H. and Ainin, S. (2015). Investigating Knowledge Sharing Behavior in Academic Environment. Journal of Organizational Knowledge Management, 2015(1): 1-19.

Meniado, J., (2020). Organizational Citizenship Behavior and Emotional Intelligence of English Foreign Language Teachers in Saudi Arabia: Implications to Teaching Performance and Institutional Effectiveness. Arab World English Journal, 11(4): 3-14.

Mustafa, E., kheder, M. and Abdelwahid, A. (2021). Job Crafting, Work Involvement and Organizational Citizenship Behavior among Head Nurses. Annals of the Romanian Society for Cell Biology, 25(4): 17045-17060. Novitasari, D., Haque, M., Supriatna, H., Asbari, M. and Purwanto, A. (2021). Understanding the Links between Charismatic Leadership, Intrinsic Motivation and Tacit Knowledge Sharing. International Journal of Social and Management Studies, 2(3): 1-13.

Obrenovic, B., Jianguo, D., Tsoy, D., Obrenovic, S., Khan, M. and Anwar, F. (2020). The Enjoyment of Knowledge Sharing: Impact of Altruism on Tacit Knowledge-Sharing Behavior. Frontiers in Psychology, 11(1):1-16.

Organ, D., Podsakoff, P. and Mackenzie, S. (2015): Organizational citizenship behavior: Its nature, antecedents, and consequences, 7(1):327-340.

Rosle, N., Idrus, R., Jamil, N. and Manan, D. (2021). Organizational Citizenship Behavior Practices among Employees in Academic Institution. Asian Journal of Behavioral Sciences, 3(1): 54-59.
Safan, S., Diab, G. and Rashad, R. (2018). The Relationship between Organizational Citizenship Behavior and Organizational Climate among Nursing Staff. International Journal of Nursing research, 4(4): 1-8.

Wang, X. (2010). An Empirical Investigation of Personal and Social Factors on Knowledge Sharing in China, Unpublished Master's Thesis. University of Twente: 54-57. Retrieved

fromhttp://essay.utwente.nl/60181/1/MAthesi s_X_Wang.pdf.

Yaakobi, E. and Weisberg, J. (2020). Organizational citizenship behavior predicts quality, creativity and efficiency performance: The roles of occupational and collective efficacies. Frontiers in Psychology Journal, 11(1): 1-18.

Zakaria, E. (2019). Relationship between organizational commitment and knowledge sharing among staff nurses. Published Master's Thesis, Ain Shams University, Egypt: 17-19. 
مشاركة المعرفة وعلاقتها بسلوكيات المواطنة المؤسسية كما يدركها الممرضون

$$
\text { آيه اسماعيل ابر اهيم ححم - فوزية فاروق كامل السيد- شيماء حمح عربي ابر اهيم }
$$

إن بناء ثقافة مشاركة المعرفة ضروري للممرضين لتحسين سلوكيات المو اطنة المؤسسية لديهم. لذلك هدفت هذه الرسالة إلى تقييم مشاركة المعرفة وعلاقتها بسلوكيات المواطنة المؤسسية كما بدركها الممرضون. وقد تم استخدام التصميم الارتباطي الوصفي لإجراء هذه الدراسة. وقد أجريت هذه الدر اسة في جميع وحدات الرعاية الحرجة بمستثفى بنها الجامعي على ( · . ( ) ممرض وممرضة. وقد تم استخدام أداتين لجمع البيانات؛ استبيان مشاركة المعرفة واستبيان سلوكيات المواطنة المؤسسية. وقد أظهرت النتائج ان ○.19\% من المدرضين لديهم مستوى أدر الك عالٍ من مشاركة المعرفة و Nv\% لايهم مستوى عالٍ من سلوكيات المواطنة المؤسسية. لخصت الدراسة وجود علاقة ارتباط موجبه ذات دلالة إحصائية عالية بين مشاركة المعرفة وسلوكيات المواطنة المؤسسية. وقد أوصت الدر اسة بتعزيز وعي الممرضون عن مشاركة المعرفة وسلوكيات المو اطنة المؤسسية من خلال عقد البر امج التعليمية وورش العمل و المؤتمر ات لتحسين النتائج المتعلقة بالمرضى و المؤسسة. 